MAgDALENA SASIN

\title{
Słuchanie - odtwarzanie - tworzenie zintegrowane, czyli o rozwijaniu zdolności muzycznych dzieci najmłodszych
}

\section{Wstęp}

Współczesna kultura kładzie nacisk na wyjątkowość i niepowtarzalność każdego człowieka. Indywidualność jest dziś ceniona bardziej niż na przykład umiejętność współpracy w grupie czy precyzja wykonywania zadań. Jest to więc jedna z najsilniejszych tendencji współczesnego świata, ma ona jednak różne oblicza; do jej pozytywnych stron należy niewątpliwie podkreślanie w niespotykanym dotąd zakresie roli i znaczenia jednostki, co wiąże się z wielką tolerancją wobec osobistych wyborów i decyzji. Stwarza to korzystne warunki dla osiągnięcia celu kluczowego dla klasycznej pedagogiki kultury: jednostkowej niepowtarzalności osobowości.

W kształtowaniu indywidualności znaczącą rolę odgrywa sztuka jako ta dziedzina ludzkiej aktywności, w której niedyrektywność i swoboda myślowa zawsze przejawiały się najsilniej. Wśród różnych dziedzin sztuki, z kolei do asemantycznych w największym stopniu, a zatem stwarzających możliwość największej liczby różnorodnych interpretacji, należy muzyka. Choć jej dzieła nie dokumentują dokonań i zmian w historii ludzkości w tak dosłowny sposób, jak choćby literatura, nie umniejsza to jej znaczenia dla wyrażania ludzkiego ducha i myśli, bowiem: „Muzyka jest czymś specyficznym dla ludzkości. Tak jak inne sztuki, jest ona podstawą ludzkiego rozwoju i egzystencji w takim samym stopniu co język" - pisze Edwin Elias Gordon (1997, s. 6-7), badacz i pedagog, autor teorii z zakresu pedagogiki muzycznej. Warto zatem przyjrzeć się, jak współczesne społeczeństwo, nastawione na kształtowanie i wspieranie indywidualności jednostki od najmłodszych lat, stymuluje rozwój zainteresowań i uzdolnień muzycznych dzieci. 
W ostatnich latach w Polsce dynamicznie rozwija się niestandardowa oferta edukacyjna dla najmłodszych - kluby malucha, kluby twórczej zabawy i pracownie artystycznych warsztatów dla dzieci powstają w lawinowym tempie. Ich popularności sprzyja z jednej strony coraz większa świadomość dorosłych w zakresie prawidłowości rozwojowych dziecka i poczucie odpowiedzialności za stworzenie mu jak najlepszych warunków rozwoju już od pierwszych chwil życia, z drugiej zaś strony - tendencja do ograniczania liczebności rodzin, która takie działania z finansowego i organizacyjnego punktu widzenia znacząco ułatwia.

Ta kwestia wpisuje się w podejmowane coraz częściej rozważania na temat „wyścigu szczurów od kołyski”. Jak każde zjawisko, także i to ma różne oblicza. Tutaj można jedynie dodać na marginesie, że poszczególne zajęcia stymulujące rozwój dziecka mają niewątpliwie wpływ korzystny - ewentualne ujemne skutki „przestymulowania” dziecka, które zamiast nieskrępowanej zabawy w pocie czoła zdobywa kolejne umiejętności, związane przede wszystkim z intensywnością proponowanych mu aktywności i wybujałymi ambicjami rodziców czy opiekunów. Same zajęcia jako takie, jeśli są prowadzone w dostosowanej do wieku dziecka formie zabawy, nie przynoszą skutków negatywnych, gdyż właśnie poprzez zabawę dziecko uczy się i poznaje świat.

W tym miejscu chciałabym szerzej opisać edukacyjną ofertę dla dzieci przygotowaną przez Filharmonię Łódzką, jej teoretyczne podstawy i praktyczne sposoby realizacji.

W styczniu 2010 r. w Filharmonii Łódzkiej rozpoczęto organizowanie zajęć muzycznych dla dzieci w wieku do lat trzech pod nazwą „Baby Boom Bum”. Warto dodać, że pomysłodawczynią tych zajęć była Dominika Jakubowska, jedna z pracownic Działu Programowego Filharmonii, muzyk z wykształcenia, prywatnie mama małej dziewczynki. Macierzyństwo skierowało jej zainteresowania ku nowatorskim formom kształtowania wrażliwości muzycznej dzieci najmłodszych. Jako pierwsza osoba w Łodzi ukończyła Kurs Gordonowski organizowany przez Fundację Kreatywnej Edukacji przy współpracy z Polskim Towarzystwem Edwina E. Gordona i, korzystając z metody prof. Gordona, zaproponowała koncepcję zajęć dla dzieci najmłodszych.

W literaturze pedagogicznej można odnaleźć stosunkowo dużo pozycji na temat percepcji muzyki przez dzieci w wieku przedszkolnym i pożądanych sposobów ich umuzykalniania (Malko, red., 1988; Zwolińska, red., 1997; Kataryńczuk-Mania, 2009). Znacznie mniej uwagi poświęca się natomiast umuzykalnianiu dzieci najmłodszych - od urodzenia do trzeciego roku życia. Jest to okres, kiedy większość dzieci nie podlega jeszcze oddziaływaniom instytucjonalnym - w Polsce do żłobków uczęszcza zaledwie $2,6 \%$ dzieci w wieku do trzech lat ${ }^{1}$. Uważa się, że dla dzieci w tym wieku najważniejsze jest zapewnienie właściwej opieki

${ }^{1} \mathrm{http}: / /$ www.stat.gov.pl/cps/rde/xbcr/gus/PUBL_zos_podst_dane_z_zakr_ochr_zdr_w_2009.pdf, 29.03.2011, dane za 2009 rok. 
zdrowotnej oraz poczucia bezpieczeństwa i stabilnego środowiska emocjonalnego. Niewątpliwie aspekty te są kluczowe, jednak nie można zaniedbywać także rozwoju intelektualnego dzieci. Środowisko i stymulacja dzieci najmłodszych mają znaczący wpływ na kształtowanie ich potencjału twórczego oraz na rozwijanie umiejętności przydatnych w późniejszej nauce szkolnej, takich jak pamięć, koncentracja czy kojarzenie.

Rozwojowi tych dyspozycji w zakresie muzyki u dzieci najmłodszych poświęcił szereg badań Edwin Elias Gordon (1927), amerykański pedagog i psycholog muzyki oraz muzyk jazzowy. W latach 1975-1997 związany był z Katedrą Badań Muzyczno-Edukacyjnych im. Carla E. Seashore'a na Uniwersytecie w Temple w Filadelfii. Opracował tzw. sekwencyjną teorię uczenia się muzyki, która przyniosła mu wiele nagród. Koncepcja ta, potwierdzona badaniami empirycznymi, spotkała się z dużym zainteresowaniem specjalistów z wielu krajów. Obecnie w Buffalo w stanie Nowy Jork działa The Gordon Institute for Music Learning (Instytut Nauczania Muzyki Gordona). W Polsce teorię Gordona promuje zwłaszcza Polskie Towarzystwo E. E. Gordona mające siedzibę w Bydgoszczy.

E. Gordon kładzie nacisk na zapoznawanie dzieci z muzyką od pierwszych chwil życia, gdyż możliwości uczenia się dziecka są tym większe, im jest ono młodsze. Okresem decydującym dla rozwoju są pierwsze trzy lata życia, kolejnym niezwykle ważnym - okres do ukończenia piątego roku życia. Zaniedbań, które nastąpiły w tym okresie, nigdy już w pełni nie da się nadrobić. Dlatego właśnie „ci, którzy dużo wiedzą o rozwoju dziecka, żartują czasami, że chcieliby umrzeć jako małe dzieci, ale najpóźniej jak tylko byłoby to możliwe" (Gordon, 1997, s. 5).

„Możliwości uczenia się nigdy nie są większe niż w chwili narodzin - pisze Gordon. Wobec tego przyjmując, że najważniejszym okresem dla uczenia się jest czas od pierwszych chwil po urodzeniu (a może jeszcze przed tym faktem) do ukończenia trzeciego roku życia, należy kierować dzieckiem tak, aby odbierało nieustrukturowane, nieformalne oddziaływania. Kolejny pod względem ważności okres to lata między trzecim a piątym rokiem - okres oddziaływań już ustrukturowanych, ale wciąż nieformalnych, realizowanych przez dom rodzinny lub przedszkole. To, czego dziecko uczy się podczas pierwszych pięciu lat życia, tworzy podstawę dla całej późniejszej edukacji, która tradycyjnie rozpoczyna się wraz z przekroczeniem progu przedszkolnej czy szkolnej »zerówki«. Im wcześniej dziecko uzyska tę podstawę, tym więcej skorzysta z późniejszej edukacji i odwrotnie - im później tego dokona, tym gorsze będą dalsze efekty. Po raz drugi nie powtórzy się okazja do nadrobienia tych zaniedbań, a nauczanie w takiej sytuacji będzie miało charakter jedynie wyrównawczy, a nie wzbogacający" (Gordon, 1997, s. 5).

W teorii E. E. Gordona centralne miejsce zajmuje pojęcie audiacji. Jest to słuchanie muzyki i przetwarzanie jej w umyśle - słyszenie wewnętrzne, które występuje wtedy, gdy dźwięk w danym momencie fizycznie nie występuje. Audiacja jest dla muzyki tym, czym wyobrażanie sobie słów dla mowy i języka. Jest to zjawisko niezbędne, by mogła zaistnieć improwizacja i jakakolwiek muzyczna ekspresja, 
a zatem zajęcia z najmniejszymi dziećmi powinny służyć przede wszystkim kształceniu tej właśnie umiejętności. Zajęcia takie wprowadzają w kulturę muzyczną dzięki dostarczaniu materiału słuchowego urozmaiconego tonalnie i rytmicznie. Gordon uważa bowiem, że naukę muzyki, podobnie jak naukę języka, należy rozpoczynać zawsze od inkulturacji, czyli gromadzenia słownika i rozróżniania struktur muzycznych.

Kolejne niezwykle ważne w tej teorii pojęcie to akulturacja. Należy ją rozumieć jako poznawanie muzyki przez dzieci najmłodsze drogą słuchania i naśladowania. Proces ten przebiega podobnie jak akulturacja językowa (Gordon, 1997). Bardzo ważne jest, by pierwsze stadium akulturacji muzycznej miało miejsce do 18 miesiąca życia, gdyż później dziecko jest bardzo zaangażowane w rozwój mowy, co odsuwa na dalszy plan inne rodzaje aktywności poznawczej. Akulturację wspiera słuchanie śpiewanek i rytmiczanek oraz wykonywanie ich wspólnie z dorosłym. Prawidłowo przebyta akulturacja sprzyja kolejnym stadiom poznawania muzyki, którymi są: imitacja (naśladowanie dźwięków muzyki z otoczenia) i asymilacja (zaangażowanie w wykonywanie muzyki ze świadomością skierowaną na siebie, koordynacja śpiewania i recytowania z oddychaniem i ruchem).

Podczas zajęć prowadzonych metodą Gordona struktury dźwiękowe wykonywane są przede wszystkim głosem. Początkowo dzieci słuchają melodii bez tekstu. Prezentowany dzieciom materiał muzyczny nie jest ograniczony do tonalności dur-moll, na której najczęściej oparte są piosenki i melodie dla najmłodszych oraz większość tzw. piosenek popularnych; wykorzystuje także inne skale, m.in. modalne, oraz nieparzyste miary taktów. Wszelkie działania połączone są z ruchem, gdyż wspiera on kształtowanie zarówno poczucia tonalnego, jak i rytmicznego. Zajęcia dla najmłodszych sprzyjają też rozwojowi tzw. paplaniny muzycznej, co jest ważnym etapem rozwoju muzycznego dziecka i wpływa na poziom jego muzykalności w dalszym życiu. Zjawisko to zostało nazwane na wzór paplaniny słownej.

Zalecenia Gordona podbudowane są obserwacjami sytuacji z życia codziennego. Przeciętne niemowlęta w swoim otoczeniu znacznie częściej mają kontakt ze słowami niż z muzyką. Jeśli nawet ją słyszą, jest to zwykle sprawa przypadku, np. ekspozycji na przekazy mediów. Ubóstwo stymulujących bodźców muzycznych sprawia, że dzieci nie mają okazji, by przyswoić sobie dźwięki muzyczne podobnie jak dźwięki mowy. Rozwój ich paplaniny muzycznej zostaje więc zahamowany.

Zjawisko paplaniny muzycznej to nie jedyna analogia między dźwiękami a słowami, na jaką zwraca uwagę E. Gordon. Cały proces poznawania muzyki porównuje on do nauki mowy, ojczystego języka. Takie porównanie może być szczególnie przekonujące dla rodziców i opiekunów: wiele osób nie czuje się bowiem na siłach wprowadzać dzieci w świat muzyki, argumentując to brakiem słuchu muzycznego, umiejętności, wiedzy itd., podczas gdy nikt chyba nie ma takich wątpliwości w odniesieniu do nauki języka ojczystego. W tym przypadku opory nie towarzyszą nawet tym, którzy wysławiają się niepoprawnie czy mają stosunkowo ograniczony zasób słownictwa. Podobnie powinno być z muzyką - to najbliżsi 
dorośli mają wprowadzać dziecko w jej świat. Jest to bowiem potrzebne mu tak samo, jak wprowadzanie go w świat słów i ich znaczeń.

$\mathrm{Z}$ analogii między mową a muzyką wynikają dalsze prawidłowości i wskazówki. Zdecydowanie nie należy wymagać od dziecka śpiewania piosenek, z tekstem lub bez, zanim nie nauczy się ono śpiewania motywów tonalnych i powtarzania motywów rytmicznych. Nacisk na powtarzanie gotowych utworów można porównać z sytuacją uczenia dziecka wierszy, zanim zacznie wymawiać pojedyncze słowa. Podobnie błędne jest uczenie śpiewania jedynie w grupie, np. w chórze; tę sytuację można porównać do mówienia tylko chórem - wówczas dziecko nie miałoby możliwości wyrażenia swoich myśli, uczyłoby się jedynie naśladowania, nie nadając słowom odpowiedniego znaczenia.

Podobnie jak słowa, muzyka i dźwięki pełne są znaczeń. Powinny zatem służyć dzieciom do nieskrępowanego wyrażania siebie, między innymi podczas improwizacji. Tylko wówczas dziecko będzie w stanie zrozumieć wypowiedzi muzyczne innych osób, czyli na przykład - we właściwym czasie - utwory muzyczne ze światowego dziedzictwa kulturalnego.

Przedstawione pokrótce zasady muzycznego rozwoju dziecka są sprzeczne z wieloma powszechnymi przekonaniami na temat tego, jak należy uczyć malców muzyki. Warto zwrócić uwagę, że rozwój muzyki w ostatnich latach, zwłaszcza w II połowie XX w., pokazał, że dotychczasowe reguły, które wydawałyby się nienaruszalne, można i należy podać $\mathrm{w}$ wątpliwość, a $\mathrm{z}$ ich zanegowania biorą się wspaniałe pomysły i wybitne osiągnięcia. „W muzyce powinna być obecna melodia”; ,rytm nie może być podstawą formotwórczą dzieła”; „w nutach należy zapisać dokładnie przebieg utworu” czy nawet: „w muzyce muszą pojawić się muzyczne dźwięki” - wszystkie te, na pierwszy rzut oka niebudzące wątpliwości, twierdzenia udało się kompozytorom zanegować i stworzyli dzięki temu dzieła interesujące i wartościowe. Tymczasem powszechna edukacja muzyczna dzieci wciąż wydaje się tkwić w miejscu, ślepa i głucha na to, co dzieje się w „,prawdziwej” muzyce. Zajęcia prowadzone z uwzględnieniem metod Edwina E. Gordona i Carla Orffa pokazują, że można i należy odejść od mozolnego i niezbyt atrakcyjnego dla najmłodszych, schematycznego nauczania piosenek, czasem ledwie wzbogaconego skromnym układem ruchowym. Należy przełamać lęk przed nieskoordynowanym gwarem, bałaganem, tarzaniem się po podłodze. Należy przełamać lęk przed muzyką.

\section{Zajęcia „Baby Boom Bum” jako przykład zastosowania metody E. E. Gordona}

Zasady metody Edwina E. Gordona są przestrzegane podczas zajęć „Baby Boom Bum" w Filharmonii Łódzkiej. W zajęciach najmłodsi biorą udział wraz z rodzicami. Zapewnienie im bezpieczeństwa emocjonalnego jest najważniejszym 
i podstawowym warunkiem, by mogły otworzyć się na bodźce z zewnątrz. Dzieci bowiem, w odróżnieniu od dorosłych, są w stanie ujawnić swój potencjał twórczy tylko w sprzyjającym, bezpiecznym środowisku (Szmidt, 2007, s. 178). Stąd szczególną wagę przykłada się do stworzenia dla małych uczestników przyjaznego otoczenia. Zajęcia odbywają się w niewielkiej sali, odizolowanej od gwaru i dźwięków, jakie towarzyszą dniu codziennemu w instytucji takiej jak filharmonia, na podłodze przykrytej tkaninami. Istotna jest także wielkość grup: jednorazowo w zajęciach może brać udział nie więcej niż 15 dzieci, a każdemu z nich może towarzyszyć maksymalnie dwoje opiekunów (najczęściej są to rodzice). Zajęcia prowadzą jednocześnie dwie osoby, a odbywają się one w trzech grupach wiekowych: dla dzieci do 12 miesięcy, od roku do dwóch lat i od lat dwóch do trzech.

Tu należy odrzucić skojarzenia, które jako pierwsze przychodzą do głowy na słowa „zajęcia”, „prowadzący”, „grupa”. Nie ma oczywiście ławek ani krzeseł, nie ma tablicy. Co więcej, nie ma też prób wprowadzenia w grupie porządku na zasadzie: „każdy robi to samo”. Od najmłodszych nie oczekuje się bowiem określonej, ukierunkowanej aktywności. Wystarczająco angażującym i ważnym dla nich zadaniem jest po prostu obecność w miejscu, w którym „dzieje się” muzyka. Mogą przyglądać się temu, co się właśnie odbywa, mogą biegać (raczkować, pełzać) dookoła sali, mogą spać albo przytulać się do rodziców.

Dzieci odrobinę starsze - 2-3-letnie - zachęcane są do konkretnych zabaw i aktywności: wykonywania prostych ruchów ciałem, np. skłonów, klaskania, zabawy kolorowymi chustami. Odbywa się to jednak w atmosferze swobody - prowadzący starają się zaciekawić dzieci tym, co robią, i skłonić je do włączenia się do zabawy, nie zaś wywierać na nie presję. Zastosowanie niewielkiej liczby prostych rekwizytów, takich jak kolorowa chusta animacyjna, nie zaburza poczucia bezpieczeństwa dzieci, rozbudza zaś ich ciekawość, wyobraźnię i fantazję.

Organizatorzy zajęć „Baby Boom Bum” początkowo obawiali się nieco, czy spotkają się one z zainteresowaniem. Umuzykalnianie niemowlą - to brzmi przecież dość odważnie. Okazało się jednak, że obawy były bezpodstawne. Zajęcia od samego początku gromadziły komplet uczestników.

Pozytywny odbiór nowej i dość odważnej propozycji artystyczno-edukacyjnej wśród łodzian potwierdza certyfikat Miejsca Przyjaznego Dzieciom, przyznany Filharmonii Łódzkiej w 2010 r. (Kołakowska, Urazińska, 2011). Certyfikatem tym wyróżnia się miejsca publiczne i instytucje, które stwarzają dogodne i przyjazne warunki dla rodziców z dziećmi, a nadaje go redakcja łódzkiego oddziału „Gazety Wyborczej" na podstawie zgłoszeń i opinii czytelników.

Rodzice uczęszczający z dziećmi na zajęcia „Baby Boom Bum” w Filharmonii Łódzkiej dostrzegają różnorodne korzyści, jakie zajęcia te przynoszą ich synom i córkom. Ich zdaniem, godne uwagi są zwłaszcza następujące zjawiska: 
- zwiększona wrażliwość na odgłosy z najbliższego otoczenia: „[dwuipółletni] Leon bardzo muzycznie się rozwinął: śpiewa, tańczy, naśladuje różne dźwięki, szczególnie śpiew ptaków"2;

- zwiększenie spostrzegawczości muzycznej, co wyraża się w reakcjach na muzykę - jej tempo, wysokość dźwięku, nastrój itd.: „[syn] żywo reaguje na muzykę, słucha w skupieniu, porusza się, gdy słyszy rytm, a czasem nawet sobie podśpiewuje, mimo że jeszcze nie mówi”; ,[syn] bardzo polubił słuchanie muzyki oraz zabawy z melodią i rytmem. Chętnie tańczy i skacze, gdy tylko usłyszy muzykę”; „zauważyłam, że [jedenastomiesięczna] córka rytmicznie się porusza i bardzo lubi w domu tańczyć";

- rozwój społeczny dzieci, kontakt z rówieśnikami: „Dla dziecka te warsztaty za każdym razem są wielkim przeżyciem; to nie tylko spotkanie z muzyką, ale także kontakt z innymi dziećmi i z prowadzącymi”; ,[syn] coraz odważniej muzykuje w grupie" (na marginesie warto zauważyć, że spotkania te są atrakcyjne ze względów społecznych także dla rodziców, zwłaszcza przebywających na urlopie wychowawczym, którzy dzięki temu mają okazję do spotkania z innymi dorosłymi, wymiany poglądów, zawarcia znajomości);

- rozwój koncentracji: „,młodsza [córka], dziesięciomiesięczna, obserwowała i na swój sposób poddawała się wykonywanym ćwiczeniom. Ale przez pół godziny była skupiona i nie znudziła się”; „na warsztatach [trzyletni syn] nauczył się skupiać uwagę na dźwiękach".

Rodzice w swych wypowiedziach ujawniają, być może nieświadomie, jeszcze jeden ważny rezultat zajęć: udział w warsztatach i obserwacja żywych reakcji najmłodszych skłaniają ich do kontynuowania niektórych ćwiczeń w domu, choćby dlatego, by sprawić najmłodszym radość. Rodzice przyznają: ,zauważyliśmy, że dzięki nim [zajęciom] syn częściej naśladuje dźwięki - dlatego ćwiczymy to również w domu”. „Na warsztaty chodzimy od roku. W domu też śpiewamy i tańczymy". Wydaje się więc, że warsztaty są swego rodzaju katalizatorem aktywności rodziców nakierowanej na artystyczny rozwój dziecka. Ten proces nie dokonuje się bowiem samoistnie - musi mieć swój początek w bodźcach $\mathrm{z}$ otoczenia.

Zajęcia z cyklu „Baby Boom Bum” oddziałują zatem na dzieci najmłodsze dwutorowo: bezpośrednio oraz pośrednio - poprzez kształtowanie środowiska, w jakim one przebywają i wzrastają. Rodzice przychodzący z maluchami do filharmonii początkowo na ogół oczekują, że zajęcia będą polegały na prezentowaniu muzyki ich dzieciom, a funkcja dorosłych ograniczy się do doglądania pociechy. Wkrótce orientują się z niejakim zdziwieniem, a czasem nawet z obawą, że to oni muszą najpierw na tę muzykę się otworzyć. Dla swoich dzieci to rodzice są bowiem najważniejszymi nauczycielami świata, oni więc powinni wprowadzać je w sztukę dźwięków i pokazywać, jak dużo jest ich w naszym otoczeniu. Prowadzący zajęcia pełnią

${ }^{2}$ Opinie rodziców dzieci uczęszczających na warsztaty muzyczne „Baby Boom Bum” w Filharmonii Łódzkiej w sezonie artystycznym 2010/2011. 
tylko funkcję pomocników i doradców. Dorośli, początkowo niechętnie, próbują więc kołysać się z dziećmi w rytm prostych melodii, rytmicznie stukać, a wreszcie zaczynają nieśmiało i cichutko nucić. Przełamują lęk przed muzyką, który u większości dorosłych jest głęboko zakorzeniony. Nie pamiętają już, że jako dzieci muzyki nie bali się wcale. Teraz dzięki swoim własnym synom i córkom mają szansę przypomnieć sobie ten wspaniały stan. Rolę rodziców w rozbudzaniu kreatywności dzieci podkreśla wielu badaczy, m.in. Janina Uszyńska-Jarmoc (2003).

\section{Kultura muzyczna - poważny problem edukacyjny}

Jeszcze niedawno pomysł uczenia dorosłych ludzi śpiewania kołysanek własnym dzieciom zostałby uznany za całkowicie niezrozumiały, wręcz absurdalny. Współcześnie jesteśmy jednak świadkami narastania zjawiska zinstytucjonalizowanego i zorganizowanego przekazywania takiej wiedzy i umiejętności, które jeszcze niedawno nabywane były naturalnie w toku socjalizacji, wychowania i kształcenia. Czytelne odręczne pisanie, gotowanie zup, pakowanie prezentów, pisanie (formułowanie treści) listów czy nawet plecenie warkoczy - tego wszystkiego uczy się obecnie na różnego rodzaju kursach. Okazuje się, że jest to potrzebne. Nauczyciele skarżą się bowiem, że większość dzieci przychodzących po raz pierwszy do przedszkola czy szkoły nie zna niemal żadnych piosenek, rymowanek, zabaw z muzyką (choćby w rodzaju Stary niedźwiedź mocno śpi czy Siała baba mak) - rodzice nie uczą ich tego.

Społeczna akcja „Cała Polska czyta dzieciom”, zapoczątkowana w 2001 r., zwróciła uwagę większości Polaków na konieczność zapoznawania najmłodszych $\mathrm{z}$ literaturą i słowem pisanym oraz na rolę rodziców w tym procesie. Czytanie dzieciom stało się czynnością popularną, a nawet modną, jako aktywność wspierająca ich rozwój i pogłębiająca więź z najbliższymi. W wielu domach stało się to rytuałem, któremu poświęca się określony czas, np. wieczorami, przed snem. Podobna akcja byłaby w Polsce bardzo potrzebna także w zakresie muzyki. Kultura muzyczna w naszym kraju stoi bowiem na niskim poziomie. Nie należy do rzadkości sytuacja, gdy student specjalności „Pedagogika - Edukacja przez Sztukę” na zajęciach artystycznych nie chce zaśpiewać ani jednego dźwięku! Trzeba wiele cierpliwości i wyjaśnień, by zachęcić go do podjęcia próby muzykowania.

Wydaje się, że można wskazać dwie zasadnicze przyczyny tego stanu rzeczy: pierwsza to postępująca mediatyzacja rzeczywistości i dnia codziennego - łatwiej włączyć płytę lub odtwarzacz mp3 niż samemu zaśpiewać piosenkę, druga - słabe tradycje muzyczne w naszym kraju w porównaniu do innych narodów, np. do ościennych Niemiec. Niemcy są przykładem na to, jak duże znaczenie mają bogate i głęboko zakorzenione tradycje muzykowania amatorskiego, zarówno domowego, jak i zbiorowego. Tradycje te wynikają m.in. z oddziałującej tam do dziś 
kultury wykształconego mieszczaństwa, tzw. Bildunsgbürgerturm (Kaiser, 2010, s. 24-25) - stąd powszechność takich zjawisk, jak chóry amatorskie, lekcje muzyki dla dzieci, regularne bywanie na koncertach abonamentowych w filharmonii czy w operze. Muzyka w życiu codziennym większości Niemców jest stale obecna, o czym świadczą choćby setki amatorskich chórów robotniczych działających do dziś w Zagłębiu Ruhry. Zagadnienia związane z życiem muzycznym regularnie pojawiają się $\mathrm{w}$ debacie publicznej, podobnie jak w Polsce sprawy związane z piłką nożną czy budową stadionów. Odbywający się w 2010 r. w Warszawie Konkurs Chopinowski wzbudzał w Niemczech znacznie większe zainteresowanie niż w Polsce, a gazety publikowały obszerne i fachowe recenzje konkursowych wykonań bez obaw o spadek czytelnictwa.

W Polsce nie tylko dziś, ale i w przeszłości dostrzegano problem niskiego poziomu kultury muzycznej, o czym świadczą takie próby wprowadzenia muzyki „pod strzechy”, jak 12 tomów Śpiewników domowych Stanisława Moniuszki. Obecnie mało kto śpiewa po prostu z umiłowania tej czynności. Nie zmieniają tu wiele liczne programy typu Mam talent, bo większość osób woli je oglądać niż naśladować ich uczestników (inna sprawa, że poziom tych programów często do naśladowania nie zachęca). Na co dzień otaczamy się muzyką, z której obecności często nie zdajemy sobie sprawy - w samochodzie, w sklepie, na ulicy. Jest ona tłem dla innych czynności, na tyle nieistotnym, że nie poświęcamy uwagi takim kwestiom, jak jakość artystycznych produkcji tego „tła”.

Wszystkie wymienione czynniki oddziałują nie tylko na percepcję muzyki $\mathrm{u}$ dorosłych, ale także na wychowanie muzyczne najmłodszego pokolenia. Większość rodziców, a nawet nauczycieli woli włączyć dziecku płytę z piosenkami niż samemu zaśpiewać. Lepsze to niż nic, takiemu rozwiązaniu daleko jednak do doskonałości - dziecko prędzej czy później zauważa, że rodzice nie śpiewają i zadaje sobie pytanie, dlaczego: nie potrafią? boją się? wstydzą? Wówczas samo zaczyna wątpić we własne możliwości. Aktywność muzyczną należy więc postrzegać nie tylko jako indywidualną ekspresję jednostki, przejaw jej zdolności i zainteresowań, ale także w kategoriach skomplikowanego systemu społecznego.

Zajęcia dla dzieci w Filharmonii Łódzkiej nie są jedynym przykładem zastosowania metody Edwina Gordona w Polsce. Warto wspomnieć m.in. o przygotowanej przez Polskie Towarzystwo Gordonowskie Podstawie programowej nauczania muzyki wedlug teorii uczenia się muzyki Edwina E. Gordona (Zwolińska, Gawryłkiewicz, 2007). Towarzystwo wydało też m.in. płyty CD z materiałem muzycznym przydatnym $w$ realizacji takich zajęć.

Gordon formułuje także zalecenia dla dzieci starszych, do lat pięciu. Tutaj można oczekiwać od dzieci większej współpracy, stąd proponowane są ćwiczenia nakierowane na pobudzanie ekspresji, a także analizowanie różnic między wykonaniami muzyki własnymi a innych osób.

W edukacji muzycznej dzieci przedszkolnych znacznie łatwiej jest wyodrębnić określone zasady i cele, gdyż na temat ich rozwoju intelektualnego i społecznego 
oraz stymulacji zdolności wiadomo o wiele więcej niż o dzieciach najmłodszych. Zwięźle formułuje to Lidia Kataryńczuk-Mania: „Cele i zadania edukacji muzycznej w przedszkolu powinny stać się fundamentem dla właściwych kontaktów z muzyką, rozwijać zdolności muzyczne i umiejętności w zakresie poczucia rytmu, melodii, pamięci, wrażliwości muzycznej” (Kataryńczuk-Mania, 2009, s. 253). Nieco dalej autorka pisze, że zadania zajęć muzycznych w przedszkolu to: pobudzanie radości dzieci, kształtowanie wrażliwości emocjonalnej na muzykę, rozwijanie umiejętności praktycznych (śpiew, gra na instrumentach, sprawność ruchowa), kształcenie postawy aktywnej i twórczej, wzbogacanie przeżyć i rozwijanie wyobraźni, poszerzanie wiedzy dziecka o otaczającym je świecie (Kataryńczuk-Mania, 2009, s. 260).

Nieco bardziej wszechstronnie cele aktywności muzycznej dziecka postrzega Janina Uszyńska-Jarmoc (2003). Autorka zwraca uwagę, że jednym z celów takich działań jest rozbudzanie zainteresowania muzyką i nawyków obcowania z nią oraz zaszczepienie przekonania, że kontakty ze sztuką dźwięków niosą przyjemność i satysfakcję. Do najważniejszych celów umuzykalniania dzieci zalicza też „rozwijanie twórczej wyobraźni muzycznej, czyli wykorzystanie zdobytych doświadczeń muzycznych do tworzenia własnych, nowych pomysłów" (Uszyńska-Jarmoc, 2003, s. 53). Zwraca uwagę, że rozwijaniu wyobraźni twórczej szczególnie sprzyjają zadania z elementami różnego rodzaju improwizacji: rytmicznych (klaskanie, stukanie), melodycznych (śpiewanie, granie na prostych instrumentach) oraz ruchowych (taniec, interpretacja ruchem słyszanej muzyki).

Pobudzanie postawy twórczej powinno być jednym z ważniejszych celów edukacji muzycznej dzieci w wieku przedszkolnym. Przedszkolaki z reguły nie odczuwają lęku przed artystycznymi próbami ani tremy przed występami publicznymi, która pojawia się u dzieci szkolnych, a swoje apogeum osiąga w okresie dojrzewania. Ich twórczość artystyczna jest jeszcze naturalna i spontaniczna - nie można tego nie wykorzystać!

Prowadzenie zajęć muzycznych z dziećmi, w tym stymulowanie ich do twórczości muzycznej, nie może się odbywać bez znajomości podstawowych prawidłowości rozwojowych. Byłoby znakomicie, gdyby taką wiedzę posiedli nie tylko nauczyciele (często im jej brakuje), ale także rodzice.

Dziecko dwu-, trzy-, czteroletnie podejmuje próby powtórzenia usłyszanej melodii, podczas gdy trzy i czterolatki są w stanie opanować jej ogólny zarys. W tym wieku dzieci zwracają uwagę przede wszystkim na wysokość i barwę dźwięków muzycznych; uczą się znacznie łatwiej, gdy melodii towarzyszą dodatkowe bodźce wzrokowe, werbalne lub motoryczne. Piosenek nie śpiewają, lecz je mówią w rytmie, ewentualnie śpiewają na jednym, wygodnym dla siebie dźwięku. Dzieci starsze, cztero- i pięcioletnie, potrafią zwykle rozróżniać rejestry wysokości i powtarzać proste rytmy. Jednak dopiero pięcio- i sześciolatki umieją rozróżniać łatwe wzory tonalne i rytmiczne, a nawet proste zjawiska dynamiczne i agogiczne (tj. $\mathrm{z}$ zakresu głośności dźwięku i tempa). By dziecko zaśpiewało poprawnie melodię wraz z jej poszczególnymi interwałami (odległościami muzycznymi), trzeba zwykle poczekać 
do jego szóstych, siódmych urodzin. Wówczas też zauważamy, że dzieci dostrzegają różnice między współbrzmieniem dysonansowym a konsonansowym, wykazują też postęp w wykonywaniu zadań twórczych (Kataryńczuk-Mania, 2009).

Prawidłowości rozwojowe dzieci bierze pod uwagę zarówno omówiona wyżej metoda Edwina E. Gordona, jak i druga znacząca metoda umuzykalniania - Carla Orffa. Nie znajdziemy tam żadnych ćwiczeń ani oczekiwań wobec dziecka, które wykraczałyby poza jego potencjalne możliwości. Teoria Gordona „stosowana” jest jednak głównie w odniesieniu do dzieci najmniejszych, podczas gdy w edukacji muzycznej przedszkolaków sięga się najczęściej do teorii - lub przynajmniej jej elementów - Carla Orffa.

\section{Metoda rozwijania zdolności muzycznych Carla Orffa}

Carl Orff (1895-1982), w odróżnieniu od Gordona, był z podstawowego swego wykształcenia muzykiem-kompozytorem. Na świecie rozsławiły go takie utwory, jak kantaty Carmina Burana i Catulli Carmina oraz opery baśniowe Księżyc i Mądra. Nie mniej istotna od dorobku kompozytorskiego jest jednak jego działalność pedagogiczna.

Orff opracował własną metodę kształcenia muzycznego, której głównym założeniem jest ścisła integracja ruchu ciała z muzyką oraz postępowanie równolegle z rozwojem dziecka. Należy sięgać do tego, co dziecku najbliższe: słowa, ruchu, otoczenia. Podstawowym założeniem Orffa było przekonanie, że niemal każde dziecko jest uzdolnione muzycznie, zdolności te należy zaś rozwijać poprzez zbiorową zabawę. Ważne okazuje się także pobudzanie dziecka do naturalnych, spontanicznych działań twórczych. Jak wyjaśnia Urszula Smoczyńska-Nachtman (1992), istota metody Orffa kryje się w tym, że „tworzenie, odtwarzanie i słuchanie stanowią integralną całość, a rozumiana w ten sposób aktywność muzyczna jest instrumentem twórczego rozwoju". Ponadto istotna jest spontaniczność, która ma dostarczać dzieciom radości z zabawy, kontaktu z drugim człowiekiem, obcowania ze światem fantazji. Dużą rolę odgrywa tu improwizacja, głównie pod postacią gry na prostych instrumentach perkusyjnych i melodycznych (ksylofony, metalofony, trójkąty, bębenki), które w Polsce znane są jako ,instrumentarium Orffa”. Instrumenty te ułatwiają zadania twórcze: bezpośrednie działanie, przeżywanie i eksperymentowanie.

Metoda Orffa wyrosła z jego idei teatru, który postrzegał jako syntezę muzyki, ruchu i słowa, i któremu dał wyraz w swoich „dorosłych” dziełach scenicznych. Wykazuje pewne związki z innymi powszechnie stosowanymi metodami muzycznego kształcenia dzieci: Emile'a Jacques-Dalcroze'a (której podstawą jest zbiorowa zabawa) i Zoltany'a Kodalya (improwizacja).

Orff skomponował szereg prostych utworów o przeznaczeniu pedagogicznym, opublikowanych w pięciu tomach dzieła Musik für Kinder, którego pierwsze wydanie pochodzi z 1950 r. Zgodnie z jego ideą należy sięgać do korzeni naszej 
kultury: starych pieśni ludowych oraz zabaw dziecięcych (do kultury i muzyki średniowiecznej nawiązują też wyraźnie inne dzieła Orffa, np. kantaty). Nie jest konieczne, by w każdym kraju wykorzystywać dosłownie ten sam materiał muzyczny - chodzi o to, by zachować pewną ideę, filozofię zapoznawania dziecka z muzyką. Zgodnie z tym założeniem, w poszczególnych krajach powstają zbiory ćwiczeń i piosenek muzycznych dla nauczycieli pracujących metodą Orffa, opierające się na rodzimym materiale muzycznym.

Metoda niemieckiego pedagoga zdobyła ogromną popularność w wielu krajach świata. Propaguje ją powołany do tego celu Orff-Institut działający przy Mozarteum w Salzburgu. W Polsce metodę tę stosuje się w edukacji muzycznej od lat 70. XX w. Propaguje ją Polskie Towarzystwo Carla Orffa mające swą siedzibę na Uniwersytecie Muzycznym Fryderyka Chopina w Warszawie. Znajduje ona zastosowanie także w muzykoterapii i rehabilitacji. Należy zaznaczyć, że koncepcja Carla Orffa w odniesieniu do dzieci w wieku przedszkolnym ma tę przewagę nad koncepcją Gordona, że jest łatwiejsza do zastosowania przez nauczycieli, z których większość ma, niestety, niedostateczną wiedzę i umiejętności muzyczne.

\section{Warsztaty „Odkrywcy Muzyki” jako przykład zastosowania metody C. Orffa}

Warsztaty dla dzieci w wieku przedszkolnym zatytułowane „Odkrywcy Muzyki”, bazujące na opisanej metodzie, odbywają się w Filharmonii Łódzkiej od kwietnia 2008 r. Organizowane są we współpracy z Polskim Towarzystwem Carla Orffa.

Zajęcia te mają charakter warsztatów kończących się koncertem. Wszystkie proponowane dzieciom działania przybierają formę zabawy. Zabawa, jak się uważa, stanowi prototyp czynności dających wykonującemu je motywację samoistną. Nie odbiera to zabawie, oczywiście, jej funkcji rozwojowej, ważnej zwłaszcza w przypadku dzieci. Zabawa dobrze też stymuluje aktywność twórczą dzieci, jest jej najważniejszą w tym okresie formą.

Podczas gdy na zajęciach „Baby Boom Bum” dominuje indywidualna aktywność dziecka (słuchanie muzyki, przyglądanie się), na warsztatach „Odkrywcy Muzyki" większą rolę odgrywa aktywność zespołowa, zbiorowa.

Dzieci podejmują działania motywowane ciekawością poznawczą - jej rozwój wpływa pozytywnie na proces twórczy, gdyż umożliwia dłuższe i intensywniejsze zajmowanie się danym problemem. Właśnie ciekawość poznawczą stymulują zajęcia typu „Odkrywcy Muzyki”, gdzie dzieci poznają nowe instrumenty (nie tylko ich dźwięk, ale już sam wygląd budzi wiele emocji!), gdzie dowiadują się, że emocje towarzyszące muzyce można wyrazić za pomocą papieru, kolorowych wstążek czy innych prostych rekwizytów, gdzie obserwują, że każdy kolega lub koleżanka z grupy ma nieco inny pomysł na to samo zadanie. Do tego typu ćwiczeń wykorzystywane 
są utwory z kanonu tzw. muzyki poważnej, np. Cztery pory roku Antonia Vivaldiego czy Eine kleine Nachtmusik Wolfganga Amadeusza Mozarta. Od malców nie oczekuje się jednak nabożnego podziwu wobec arcydzieł, nie wymaga grzecznego słuchania - po cichu i bez poruszania się. Utwory te stają się narzędziem twórczej ekspresji. Taka aktywna percepcja muzyki nie męczy, a dzięki zadaniom stawianym małym słuchaczom czas im się nie dłuży (co zdarza się nawet dorosłym melomanom zasiadającym w sali koncertowej). To tzw. sytuacja zadaniowa, która odgrywa istotną rolę w pobudzaniu myślenia twórczego (Urban-Kojs, 1996).

$\mathrm{Na}$ zajęciach dominują pytania i zadania dywergencyjne, a więc takie, które można rozwiązać, dając wiele równie dobrych lub podobnie dobrych odpowiedzi - w odróżnieniu od zadania konwergencyjnego, które wymaga jednej odpowiedzi ściśle określonej (Szmidt, 2010). Wynika to z niewerbalnego charakteru sztuki, a muzyki w szczególności oraz z przyjętej formuły prowadzenia zajęć. Nadal bowiem zdarza się, niestety, że także w zadaniach wymagających twórczej ekspresji nauczyciele czy prowadzący skłonni są uznać za prawidłowe tylko jedno, z góry przez siebie przyjęte, rozwiązanie (Szmidt, 2007, s. 208-209).

Kreatywność dzieci pobudza także organizowany co roku konkurs na Najpiękniejszy Instrument Odkrywcy Muzyki. Warto zaznaczyć, że nagrody, polegające m.in. na opublikowaniu zdjęcia instrumentu w miesięczniku programowym Filharmonii Łódzkiej, przysługują wszystkim uczestnikom konkursu. Pozwala to z jednej strony zachęcić dzieci do twórczego wysiłku - instrumenty te często są pięknie malowane, ozdabiane wycinankami, wstążeczkami itp., do tego stopnia, że ich walory estetyczne przewyższają zalety akustyczne, które trudno osiągnąć w domowych warunkach, z drugiej zaś strony - zminimalizować niekorzystne oddziaływanie rywalizacji.

Dodatkowym atutem omawianych warsztatów jest miejsce ich odbywania się: filharmonia, a zatem instytucja niekojarzona powszechnie z ocenianiem i klasyfikowaniem działań dzieci - w odróżnieniu od szkoły czy nawet przedszkola. Brak oceny produkcji artystycznych wpływa korzystnie na zaangażowanie osób, które się im oddają, zwłaszcza w przypadku twórczości dzieci i młodzieży. Prawidłowość tę potwierdza wiele badań (Uszyńska-Jarmoc, 2003; Szmidt, 2007). Aktywność twórcza przynosi najlepsze rezultaty, gdy jest postrzegana jako przyjemność i nagroda sama w sobie, nie zaś jako narzędzie do zdobycia określonej gratyfikacji. Czerpanie satysfakcji z samej czynności zwane jest motywacją samoistną lub autoteliczną (Tokarz, 2005), w odróżnieniu od motywacji instrumentalnej, w której zaciekawienie kierowane jest ku czemuś, co może się przydać, oraz od motywacji zadaniowej, powodowanej poczuciem obowiązku lub chęcią spełnienia wymagań. Warunek stymulowania motywacji samoistnej spełniają „Odkrywcy Muzyki” - dzieci uczęszczają na nie z ochotą, traktując jako wydarzenie wyjątkowe, odmienne od codziennej rutyny, np. zajęć w przedszkolu.

Podczas koncertu odbywającego się bezpośrednio po warsztatach dzieci mają możliwość zaprezentowania dopiero co zdobytych umiejętności na filharmonicznej estradzie. Taka sytuacja jest atrakcją samą w sobie: możliwość wejścia na estradę, która jawi się najmłodszym (a nawet niektórym dorosłym) jako miejsce 
zarezerwowane dla profesjonalistów, tajemnicze, może nawet nieco groźne (?), wywołuje mnóstwo żywych emocji. Występ przed najbliższymi mobilizuje i staje się wyjątkowym przeżyciem. Popisy dzieci nie zajmują całego koncertu - jego ważną częścią są występy dorosłych artystów-muzyków, prezentujących atrakcyjne dla małych słuchaczy utwory muzyczne, opatrzone słownym komentarzem. Stałym elementem programu jest też wspólne wykonanie piosenki.

Widzami koncertu są nie tylko członkowie rodzin występujących dzieci, ale także ich rówieśnicy, wysłuchanie koncertu jest bowiem możliwe bez wcześniejszego udziału w warsztatach. Dzieci, które wcześniej obawiały się wzięcia udziału w zbiorowych zajęciach i samodzielnego występu, mogą w ten sposób przekonać się, czym zajmują się ich rówieśnicy, i nabrać ochoty do wspólnych działań.

\section{Zakończenie i dyskusja}

Warto zadać pytanie o to, dlaczego zapoznawanie dziecka z muzyką jest tak ważne, szczególnie dla rozwoju jego zdolności twórczych? „Przez muzykę dziecko zyskuje wgląd w siebie i w innych oraz w samo życie i, co być może najważniejsze, muzyka umożliwia mu rozwój i utrwala wyobraźnię" - podkreśla Edwin Gordon (1997, s. 6-7). Wykorzystanie muzyki klasycznej w zajęciach z dziećmi pozwala zatem skutecznie pobudzać ich aktywność intelektualną, stymulować kreatywność, rozwijać umiejętność skupienia uwagi, a także wpływać korzystnie na rozwój społeczny.

Należy jednak zaznaczyć, że korzyści te są trudno mierzalne i często nie da się ich zaobserwować od razu, lecz dopiero po pewnym czasie. Warto podkreślić, że już jakiś czas temu obalono teorię o występowaniu tzw. „efektu Mozarta”, czyli wpływie muzyki tego kompozytora na wzrost ilorazu inteligencji. Powstanie przekonania o wyjątkowo dobroczynnym oddziaływaniu utworów twórcy Requiem było spowodowane... błędem dziennikarskim. Polegał on na nieuprawnionym uogólnieniu wyników badań, które wskazywały na stymulującą rolę Sonaty $D$-dur KV 448 podczas rozwiązywania ściśle określonego rodzaju zadań związanych $\mathrm{z}$ orientacją przestrzenną (Sachs, 2009).

Oczywiście, nie należy popadać w skrajności, kwestionując dobroczynne działanie muzyki w ogóle - jej pozytywnego wpływu dowiedziono już wielokrotnie, na tym opiera się cała koncepcja muzykoterapii, której korzenie sięgają starożytności. Należy jedynie zachować ostrożność przy formułowaniu celów i oczekiwań tam, gdzie pojawia się muzyka.

Niewątpliwie pozytywne przeżycia, takie między innymi, jakie towarzyszą warsztatom i koncertom „Odkrywcy Muzyki”, sprzyjają rozbudzaniu zainteresowań. Zainteresowania - zwłaszcza artystyczne - silnie związane są zaś z twórczością i działaniem twórczym. Dla tego procesu, podobnie jak dla wszystkich niemal dziedzin rozwoju, znaczący jest wczesny etap życia. Pod wpływem zajęć 
artystycznych dorośli mogą odkryć u dziecka zdolności, które - w odpowiedni sposób rozwijane - mają szansę stać się ważną aktywnością wolnoczasową jako zainteresowania, a nawet stanowić w przyszłości podstawę wyboru zawodu.

Warto podkreślić, że zdolności muzyczne dziecka nie są tożsame z osiągnięciami w zakresie muzyki. Zdolności te są bowiem dyspozycją wrodzoną, która może być rozwijana przez otoczenie, jednak początki tego procesu powinny nastąpić nie później niż w dziewiątym roku życia (wówczas następuje okres tzw. uzdolnień ustabilizowanych). Wiele dzieci o wysokim poziomie zdolności muzycznych ma relatywnie niskie osiągnięcia $\mathrm{w}$ tym zakresie, gdyż nie miały okazji uczenia się muzyki we właściwym wymiarze (Gordon, 1997). Udział najmłodszych w zajęciach muzycznych zapobiega takiej sytuacji.

Henryk Sikora (2005), zajmujący się wpływem postaw rodziców na rozwój uzdolnień młodszego pokolenia, stwierdził, że zainteresowania dzieci w mniejszym stopniu korelują z ich wrodzonymi uzdolnieniami, w większym zaś - z zainteresowaniami rodziców. Ich rozwojowi sprzyja „dom, w którym panuje odpowiedni klimat, w którym są zaspokajane potrzeby dziecka, a ono ma możliwość samorealizacji" (Sikora, 2005, s. 234). Takie środowisko rodzinne oddziałuje nie tylko w dzieciństwie, ale kształtuje intelektualne i emocjonalne postawy na całe życie. Postawa rodziców ma zatem niebagatelne znaczenie - nawet jeśli dzieci nie rozbudzą w sobie głębszych zainteresowań w danym kierunku, otrzymują wartościowy wzór sposobu korzystania z czasu wolnego.

Opisywane zajęcia warsztatowe w Filharmonii Łódzkiej projektowane są z uwzględnieniem prawidłowości rozwoju zainteresowań na poszczególnych etapach życia dziecka. Zajęcia podejmowane przez dzieci jako przejaw zainteresowań mają bowiem nieco inny charakter niż u osób dorosłych, zarówno pod względem treści, jak i formy: zainteresowania dziecięce są bardziej nastawione na aktywność i działanie, w mniejszym stopniu zaś konceptualne; są zwykle proste i konkretne, obejmujące swoim promieniem dość szerokie pole zjawisk, ale raczej powierzchowne. Dzieci nie są bowiem w stanie objąć - zarówno umysłowo, jak i emocjonalnie - całego bogactwa danego zjawiska. W związku z tym na ogół nie podejmują w ogóle prób podobnych rozważań, po prostu koncentrują się na działaniu, które sprawia im przyjemność. $Z$ czasem zainteresowania mają szansę zmienić się w aktywność bardziej ukierunkowaną, o węższym zakresie, jednak bardziej kompleksową i dogłębną oraz o rozwiniętym aspekcie poznawczym. Jak zaobserwował Jonathan Feinstein (2006), zajmujący się zjawiskiem zainteresowań i analizą w tym kontekście życiorysów wybitnych artystów i naukowców, u tych osób dojrzałe zainteresowania twórcze w wielu przypadkach miały swój początek w dzieciństwie.

Rozbudzaniu kreatywności i aktywności twórczej w szczególny sposób sprzyja muzyka dzięki temu, że jest ona sztuką niewerbalną. „W tej dziedzinie sztuki można działać, poszukiwać, doświadczać, badać, przeżywać, poznawać prawdziwe wartości. Muzyka jest bogatym i różnorodnym uniwersum dla rozwijania osobowości dziecka" - zauważa Lidia Kataryńczuk-Mania (2009, s. 253). Zajęcia 
muzyczne pobudzają aktywną i twórczą postawę dziecka nie tylko wobec samych zjawisk muzycznych czy szerzej - artystycznych, ale wobec całego świata. Zapewnienie dziecku warunków, by było twórcze, zwiększa szansę, że z takiego dziecka wyrośnie twórczy dorosły - niekoniecznie uznany artysta czy wynalazca, ale osoba zdolna do samodzielnych sądów i aktywnie kształtująca własne życie.

\section{Literatura}

Dane Głównego Urzędu Statystycznego, http://www.stat.gov.pl/cps/rde/xbcr/gus/PUBL_zos_podst_ dane_z_zakr_ochr_zdr_w_2009.pf, data dostępu 29.03.2011.

Feinstein J. (2006), The Nature of Creative Development, Stanford Business Book, Stanford, California.

Gmys M. (2002), Orff Carl, [w:] Encyklopedia muzyczna PWM, część biograficzna, t. „n-pa”, Polskie Wydawnictwo Muzyczne, Kraków.

Gordon E. E. (1997), Umuzykalnianie niemowlat i matych dzieci, Wydawnictwo Zamiast Korepetycji, Kraków.

Kaiser J., Zagraj Bacha po fajrancie, „Gazeta Wyborcza”, 16-17.10.2010.

Kataryńczuk-Mania L. (2009), Edukacja muzyczna najmłodszych, [w:] Edukacja małego dziecka. Refleksje, problemy, doświadczenia, A. Nowak-Łojewska, A. Olczak, A. Soroka-Fedorczuk (red.), Oficyna Wydawnicza Uniwersytetu Zielonogórskiego, Zielona Góra.

Kołakowska A., Urazińska A., Szukamy miejsc przyjaznych dzieciom, „Gazeta Wyborcza - Łódź”, 26.04.2011.

Sachs O. (2009), Muzykofilia. Opowieści o muzyce i mózgu, Wydawnictwo Zysk i S-ka, Poznań.

Sikora H. (2005), Postawy rodziców a rozwój uzdolnień plastycznych dzieci, [w:] Dylematy edukacji artystycznej, t. 1, Edukacja artystyczna wobec przemian w kulturze, W. Limont, K. Nielek-Zawadzka (red.), Oficyna Wydawnicza „Impuls”, Kraków.

Smoczyńska-Nachtman U. (1992), Muzyka dla dzieci. Umuzykalnienie wedtug koncepcji Carla Orffa, Wydawnictwa Szkolne i Pedagogiczne, Warszawa.

Szmidt K. J. (2010), ABC kreatywności, Wydawnictwo Difin, Warszawa.

Szmidt K. J. (2007), Pedagogika twórczości, Gdańskie Wydawnictwo Psychologiczne, Gdańsk.

Urban-Kojs E. (1996), W stronę osobowości twórczej, [w:] Dziecko w świecie sztuki, B. Dymara (red.), Oficyna Wydawnicza „Impuls”, Kraków.

Uszyńska-Jarmoc J. (2003), Twórcza aktywność dziecka. Teoria - rzeczywistość - perspektywy rozwoju, Wydawnictwo Trans Humana, Białystok.

Zwolińska E., Gawryłkiewicz M. (2007), Podstawa programowa nauczania muzyki wedtug teorii uczenia się muzyki Edwina E. Gordona, Wydawnictwo Kreska, Bydgoszcz. 